Military Technical College

Kobry El-Kobbah,

Cairo, Egypt

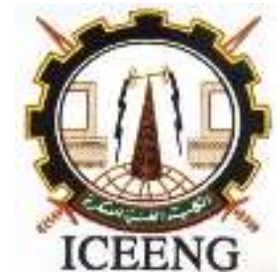

\author{
$11^{\text {th }}$ International Conference \\ on Electrical Engineering \\ ICEENG 2018
}

\title{
DESIGN AND OPTIMIZATION OF STANDALONE PHOTOVOLTAIC SYSTEM BASED ON MPPT FLC CONTROLLER FOR ELECTRIC BIKES CHARGING STATION
}

\author{
H. M. Farghally*, N. M. Ahmed*, and F. H.Fahmy*
}

\section{ABSTRACT}

This paper focuses on sizing, modeling, control and simulation of PV standalone system for powering electric bikes (E-bikes) battery charging station in Maadi region, Cairo, Egypt. The aim of the proposed PV system is to reduce the grid energy consumption and promote the use of renewable energy. HOMER software is applied for sizing and optimizing the PV charging station. Maximum power point tracking (MPPT) technique, based on the Perturb and Observe (P\&O) and fuzzy logic controller (FLC), is implemented for the PV charging station. The system has a daily load of $250 \mathrm{kWh} /$ day and $25 \mathrm{~kW}$ peak. The analysis and simulation results for both P\&O controller and FLC are also presented. The implementation of MPPT technique is carried out using MATLAB-SIMULINK software. The maximum power output reached $65 \mathrm{KW}$ when PV module is subjected to irradiance of $1000 \mathrm{~W} / \mathrm{m} 2$. FLC has better, faster response and steady state output comparing with P\&O controller

\section{KEY WORDS}

PV, E-bike, Charging Station, MPPT, FLC, Sizing, Modeling, MATLAB-SIMULINK.

\section{NOMENCLATURE}

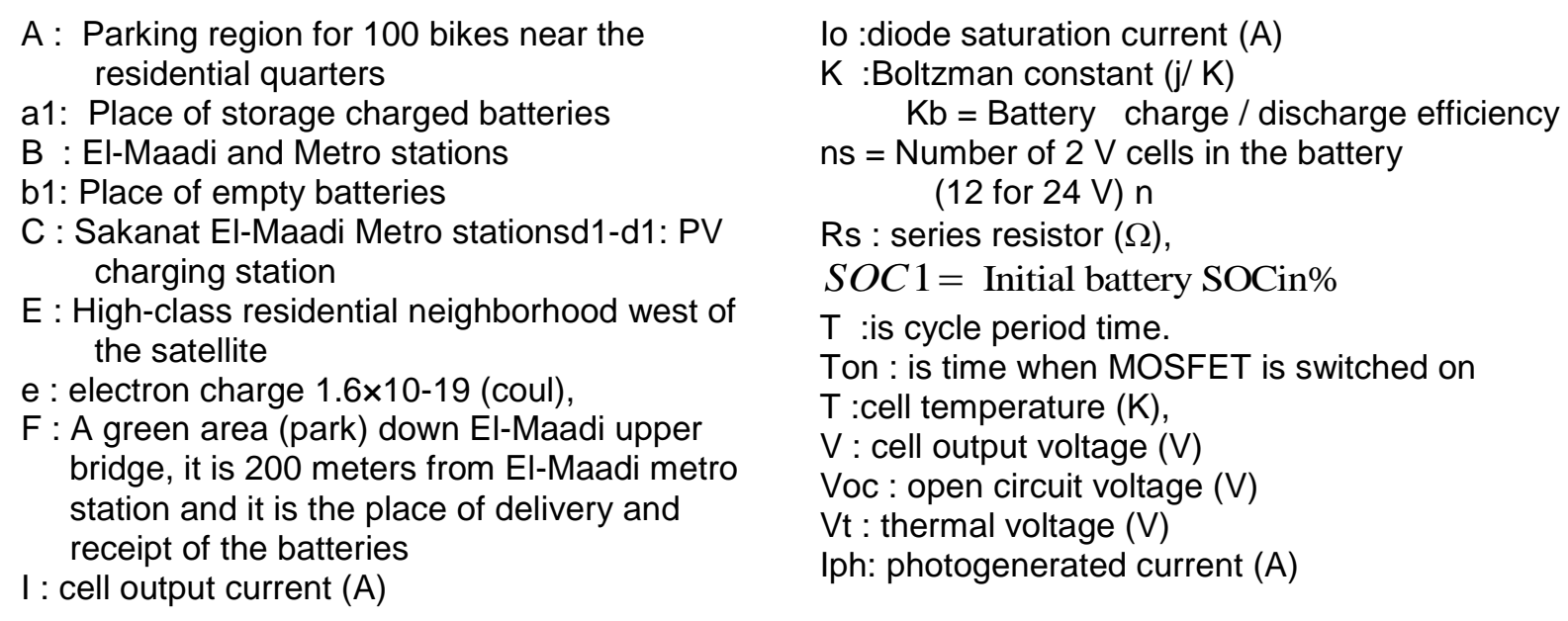

* Electronics Research Institute, Giza, Egypt. 


\section{INTRODUCTION}

Today's World transportation sector is the major polluter and energy consumer. People have become used to regularly traveling long distances to work or just for pleasure and modern lifestyles are often arranged around the permanent availability of cheap transport options [1-2]. Most of the developed countries trend towards using the bike as a mean of transport for young people and planned safe paths for bicycles in each town or district. The three most important purposes for using bikes are commuting for education, work and shopping [3-4]. The young people are the most commonly used for bikes, especially schools and university students to navigate from home to school or university. Recently, E-bike is running using a small battery mounted under the seat of the bike after mechanical starting for a minute and foot pedal torque. This means that during the journey the bike is running without effort. Use of electrical bike as a mean of transport for individuals can be applied in different suburbs in Cairo. El-Maadi is one of the districts that can be used for applying the electrical bike experience in Cairo. Thus, it is reasonable to choose the location for the E-bikes battery charging station in a public place. But the current demand for energy exceeds the available conventional resources like coal and petroleum. In addition to, the price of crude oil continues increasing significantly over the past few years and there seems to be no turning back [5]. Now, it is the time to exploiting sustainable and locally available renewable resources as the solutions need to be found to minimize the environmental impact as much and as soon as possible. Renewable Energy is clean, green, free, pollution Lows, endless energy source. Renewable energy resources such as biomass, wind, hydro and solar that can be used as a primary source of electricity and contribute to the development [6]. These resources are locally available and they are free, in addition to being environmentally friendly. Solar and wind energy are the first options on the list. It is imperative that, Egypt must devote more efforts to promoting the use of renewable energies, e.g. solar, wind, biogas, and biomass. The annual average wind speed in Cairo is 2.11 $\mathrm{m} / \mathrm{s}$, which is not sufficient to consider as an influential power source. Solar energy is inexhaustible natural and abundant resource, which is the most locally available renewable resources in Cairo. Due to its geographic location, Egypt enjoys sunshine all year, with direct solar radiation, which reaches $6 \mathrm{kWh} / \mathrm{m} 2 /$ day [7]. Therefore, it may be used for powering the E-bikes charging station. PV array is not sufficient to provide a continuous power supply due to seasonal and non-linear variation of solar radiation. To ensure a sufficient and stable power we should use batteries as a backup energy source to overcome the scare periods and meet the demand load during cloudy periods. Also, a major challenge in the use of PV is posed by its nonlinear current-voltage $(\mathrm{I}-\mathrm{V})$ characteristics, which result in a unique maximum power point (MPP) on its power- voltage (P-V) curve. In addition to, the high initial capital cost of a PV source and low energy conversion efficiency makes it imperative to operate the PV source at MPP so that the maximum power can be extracted. This work presents sizing, optimization, design and control of the standalone PV system for powering E-bikes batteries charging station at El-Maadi region, Cairo, Egypt. Sizing and optimization of PV standalone system are carried out using HOMERoptimization and simulation software tool. The PV standalone system is designed to fulfill the electricity requirement for charging $100 \mathrm{E}$ - bikes batteries. FLC based MPPT algorithm is developed, in order to achieve a variety of aims including accurate tracking, fast response and less oscillation due to the change of the solar irradiance 
and the air temperature. MPPT method using P\&O controller and FLC is simulated using MATLAB-SIMULINK package. The simulation results and analysis of P\&O and fuzzy logic control are given and discussed.

\section{SELECTED SITE}

Knowing that El-Maadi has distinctive and pioneering experience in using the bikes in the middle of the last century where the bike is the dominant and distinctive transport mean in this neighborhood. A part of the suburb of El-Maadi is selected for using the bike as a distinct transport mean from homes to El-Maadi and Sakanat El-Maadi Metro stations. A Diagram of how to apply this experience is illustrated in Fig. 1.

\section{WEATHER DATA}

Cairo is chosen as the site under consideration and it is located at coordinates 300 $05^{\prime} \mathrm{N}$ and $31017^{\prime} \mathrm{E}$ at an elevation of $34.4 \mathrm{~m}$ in the north of Egypt [8]. Figure 2 and Fig.3 illustrate the solar radiation for a typical day in summer and winter respectively. The solar radiation starts to increase at about 5:00 am and reach its peak at noon. At sunset, it starts to decrease and reach zero at around 7:00 pm. The ambient temperature for a typical day in summer and winter is shown in Fig. 4 and Fig. 5 respectively.

\section{LOAD PROFILE}

In this study, the energy required for charging a certain number of E-bike batteries in order to drive E-bike brushed DC Motors is considered as the electrical load drawn from the charging station. The specifications of the MY1016Z brushed DC Motor is given in Table 1 [9]. From the examination of these specifications, it is clear that, 250 W, 24V brushed DC motor is used for our application and the voltage required for fulfill the rated voltage of this motor is $24 \mathrm{~V}$. Therefore, a battery with rated voltage of $24 \mathrm{~V}$ is used. We assume that, there are $100 \mathrm{E}$-bikes dry cell batteries of $24 \mathrm{~V} \& 7.5$ Ah charged per day and the system is working all the week. Also, we assume that the E-bikes batteries are always being charged in the period from 7:00 am to 5:00 pm. Hourly load demand is shown in Fig. 6 and our load is $250 \mathrm{kWh} /$ day.

\section{THE PROPOSED PV SYSTEM}

Sizing and optimization of the proposed PV system is implemented using Homer "Hybrid Optimization Model for Electric Renewable" simulation tool which is developed by the U.S. National Renewable Energy Laboratory (NREL). Scheme of the proposed PV system as implemented in the HOMER is shown in Fig.7. HOMER facilitates finding the optimum solution in terms of a system's installation and recurrent costs over a specific life span [10-12]. Homer simulates the operation of a power system by making energy balance calculations for each of the 8,760 hours in a year and provides the optimal combination of components considered, receiving input data like component costs and their performances. The specifications of different components used in HOMER are explained in detail hereby. 


\subsection{PV Array}

JT180PEe module was selected for the proposed PV system. The PV module is a multi-crystalline silicon type with nominal maximum power of $180 \mathrm{~W}$, each module contains 48 cells connected in series. The specifications of the JT180PEe PV module at Standard Test Conditions (STC; $1000 \mathrm{~W} / \mathrm{m} 2$ and $25^{\circ} \mathrm{C}$ ), are listed in Table 2 [13]. The capital cost, replacement cost and operation \& maintenance cost for $1 \mathrm{KW}$ of PV array are $\$ 4000, \$ 3500$ and $(\$ / Y r) 0$ respectively, and the life time of the PV array is considered 20 years.

\subsection{Battery}

A deep cycle lead acid battery that is commonly used in renewable energy application is considered. The Surette6CS25P model battery is selected for this study. The nominal voltage and nominal capacity are $6 \mathrm{~V}$ and $1165 \mathrm{Ah}(6.94 \mathrm{kWh})$ respectively [14-15]. The capital cost, replacement cost and operation \& maintenance cost for $1 \mathrm{kWh}$ are $\$ 1145, \$ 1000$ and $(\$ / Y r) 200$ respectively.

\section{OPTIMIZATION RESULTS}

Figure 8 illustrates the optimal sizing of the PV system, the best combination that technically and economically meets the daily load of $25 \mathrm{~kW}$ peak. The optimum energy system comprises of PV array of power $65 \mathrm{~kW}$ producing $142,921 \mathrm{KWh} / \mathrm{yr}$ and 80 SuretteS6CS25P batteries connected in 20 parallel strings each string contains 4 batteries to obtain $24 \mathrm{~V}$ bus voltage. The cost of energy (COE) is found to be $0.579 \$ / \mathrm{kWh}$, whereas the initial capital cost required, and the net present cost (NPC) are, $\$ 351.600$ and $\$ 629.328$ respectively. The daily distribution of the output power generated by the PV array, the battery input power, the DC primary load and the unmet load for a typical day in the winter (Feb.) and summer (August) is shown in Fig. 9 and Fig. 10 respectively. It is observed that, there is a perfect correlation between the incident solar radiation and the produced photovoltaic power. At low irradiation, the power generated from the PV array is not sufficient to overcome the load demand and therefore the battery power is negative because there is a discharge from the battery to satisfy the required load. While if sufficient amount of solar irradiation, the generated electrical power from the PV array is greater than the power needed by the load. In this case, the energy surplus is stored in the battery and the battery is in charge state and its power is positive. Also, it is observed that, the load could be met right during the period from 7 am to $5 \mathrm{pm}$ with zero unmeet load. The PV array monthly average electricity production is shown in Fig. 11. It is shown that, summer months have the highest energy production compared to that during the winter months. PV production reaches its maximum output of $24.716 \mathrm{KW}$ in June and its minimum output of $8.377 \mathrm{KW}$ in January.

\section{MAXIMUM POWER POINT TRACKING (MPPT)}

As sunlight intensity and temperature affect the output voltage - current characteristic curve of solar cells, environmental variations change the maximum output power of solar cells. Thus, the operating points of solar cells must be changed according to working environments in order to change the output voltage and current of solar cells 
so that the maximum output power can be achieved [16]. Maximizing solar system output power can be performed using any of the three major approaches; sun tracking, MPPT or both [17]. MPPT can be implemented using conventional controller techniques such as the Perturb and Observe (P\&O) or hill climbing, incremental conductance, fractional open-circuit, current and current sweep [18]. Also, intelligent controller techniques such as Neural Networks (NN) and Fuzzy Logic Controllers can be used for MPPT implementation [19]. In this work both conventional P\&O controller and fuzzy logic controller are implemented. Figure 12 presents the block diagram of the P\&O controller and FLC for the PV system. The system consists of PV array, storage batteries, DC-DC-boost converter, fuzzy based MPPT control unit and DC electric load. Both the load and the storage batteries can be charged from the PV array using fuzzy based MPPT control unit to track the peak power generated by the PV array.

\subsection{PV System Modeling}

\subsubsection{PV array model}

The relationship between solar cell current and voltage can be described by the following equation [16]:

$$
\begin{aligned}
& I=I_{p h}-I_{o}\left(\exp \left[\frac{e\left(V+I R_{s}\right)}{K T_{\text {cell }}}\right]-1\right) \\
& V=V_{t} \ln \left(\frac{I_{p_{h}}}{I_{o}}\right)
\end{aligned}
$$

\subsubsection{Battery model}

The battery model is based on the equations described by Lasnier and Tang [], the model has the following input parameters [20]:

- Initial state of charge: SOC1 (\%), indicating available charge.

- Maximum state of charge: SOCm (Wh), maximum battery capacity.

- Number of $2 \mathrm{~V}$ series cells: ns.

- Two empirical constants depending on the battery characteristics:

- K (dimensional): charge/discharge battery efficiency;

- $\mathrm{Db}(\mathrm{h}-1)$ : battery self-discharge rate.

The electrical battery model is composed of a voltage source $\mathrm{V} 1$ in series with a resistor R1, as shown in Fig 13 [21]. The values of $\mathrm{V} 1$ and $\mathrm{R} 1$ depend on the battery operation mode at a given time. The model is restricted to two main modes of operation: charge and discharge. The implementation of the model consists basically of assigning different expressions to the values of $\mathrm{V} 1$ and $\mathrm{R} 1$ in each different mode as follows [20-22]:

Charge mode: 
$R 1=R_{c h}=\frac{0.758+\frac{0.1309}{(1.06-\beta)}}{S O C_{m}} * n s$

$V_{b a t}=V_{c h}+I_{b} R_{c h}$

Where, $\beta=S O C / S O C_{m}$

Discharge mode:

$$
\begin{aligned}
& R 1=R_{d c h}=\frac{0.19+\frac{0.1037}{(\beta-0.14)}}{S O C_{m}} * n s \\
& V_{b a t}=V_{d c h}+I_{b} R_{d c h} \\
& \left.\left.S O C_{n}(t)=S O C 1+\frac{1}{S O C_{m}} \int \frac{K V 1 I_{b a t}}{60}-\left(\frac{D_{b} S_{O C C_{n}}(t-\tau)}{60}\right) S O C_{m}\right)\right) d t
\end{aligned}
$$

\subsection{Perturb and Observe (P\&O) Controller}

One of the most widely used techniques in MPPT is P\&O due to its simple and easily implementation using a buck-boost DC-DC converter. It is able to regulate the output voltage that may be less or greater than the input voltage. [23-25]

\subsubsection{DC-DC converter}

DC-DC converter is used to regulate the power drawn from the solar array. The output of the solar array will be the input of the boost converter, which then outputs into the battery for charging. A boost converter is a step-up DC-DC power converter. The electrical circuit diagram of a boost converter using MOSFET switch is represented in Fig 14 [26]. There are two modes for a boost converter operation. Mode 1 begins when the transistor is switched ON, the current in the boost inductor increases linearly, and the diode is OFF state, mode 2 begins when the transistor is switched OFF, the energy stored in the inductor is released through the diode to the load. The power flow is controlled by varying the on/off time of the MOSFET switch [26].

The relationship between input and output voltages as function of duty cycle can be expressed by the following equation [27 -28]

$$
\frac{V_{o}}{V_{i}}=\frac{1}{(1-D)}
$$

Where $\mathrm{Vi}$ is the $\mathrm{PV}$ output voltage, VO voltage of boost converter, $\mathrm{D}$ is the duty cycle, which can be expressed by the following formula [27 -28]. 
$D=\frac{T_{o n}}{T}$

Where Ton is time when MOSFET is switched on, $T$ is cycle period time. The transistor operates as a switch; it is turned on and off depending on pulse width modulated (PWM) control signal. PWM operates at constant frequency i.e. $T$ is constant and Ton is varying, so $D$ can be varied from 0 to 1 [29].

\subsubsection{Perturb \& observe}

The principle of $\mathrm{P} \& \mathrm{O}$ is to perturbation by acting decrease or increase on the PWM duty cycle of boost converter and then observing the direction of change of PV output power. The voltage and the current produced by the PV array are measured, in order to calculate the power that is generated by the PV array. Then the power values of the present and previous states are compared. If the power does not remain the same, the algorithm checks if the differential between the power at the present and previous state is negative or positive. If at any instant $k$ the output $P V$ power $P(k)$ \& voltage $\mathrm{V}(\mathrm{k})$ is greater than the previous computed power $\mathrm{P}(\mathrm{k}-1)$ \& voltage $\mathrm{V}(\mathrm{k}-1)$, then the direction of perturbation is maintained otherwise it is reversed. If the differential is positive then the duty cycle is changing in order to keep the operation at the same direction of perturbation. If the power's difference is negative the duty cycle is changing in order to reverse the direction of perturbation [ ]. The flow chart of algorithm has 4 cases as shown in Fig.15 [30] and can be explained as following:

1- When $\Delta P<0$ \& $V(k)>V(k-1)$, this yields to $D(k)=D(k-1)+\Delta D$

2- When $\Delta P<0$ \& $V(k)<V(k-1)$, this yields to $D(k)=D(k-1)-\Delta D$

3-When $\Delta P>0$ \& $V(k)>V(k-1)$, this yields to $D(k)=D(k-1)+\Delta D$

4- When $\Delta P>0$ \& $V(k)<V(k-1)$, this yields to $D(k)=D(k-1)-\Delta D$

\subsection{Fuzzy Logic Controller (FLC)}

In this paper, FLC is proposed to be implemented in MPPT. FLC is robust and relatively simple to design since fuzzy do not require information about the exact model. In addition, fuzzy logic simplifies dealing with nonlinearities in systems, it is based on operator experience and it is very easy to apply [31-32]. The PV power at the present state will be compared with the PV power at the previous state and thus the change of power will be one of the inputs of fuzzy inference system (FIS). Another fuzzy input will be the change of power with respect to the change of voltage. Based on the changes of these two inputs, fuzzy can determine the size of the perturbed voltage. Therefore, fuzzy based MPPT can track the maximum power point faster. In addition, fuzzy can minimize the voltage fluctuation after MPP has been recognized.

A FLC is efficient to cope with continuous states with the help of membership function (MF) and IF-THEN rules. In general as shown in Fig. 16, the fuzzy logic controller includes four functional blocks: fuzzifier, rules, inference engine and defuzzifier. The fuzzy inference is carried out by using Sugeno's method [26], and the defuzzification uses the centre of gravity to compute the output of this FLC. 
Firstly, a crisp set of input data is gathered and converted to a fuzzy set using fuzzy linguistic variables, fuzzy linguistic terms and membership functions. This step is known as fuzzification. Afterwards, an inference is made based on a set of rules. Lastly, the resulting fuzzy output is mapped to a crisp output using the MFs in the defuzzification step. Mamdani triangular membership functions of the two inputs and for the output variables are considered in this paper [32]. In this case, seven fuzzy sets are used for inputs and output as shown in Fig.17 where, NB stands for negative big, NM for negative medium, NS for negative small, ZE for zero, PS for positive small, PM for positive medium and PB for positive big. In this work, the inputs of the designed fuzzy logic controller are $\Delta \mathrm{P}$ and $\Delta \mathrm{V}$ according to the same $\mathrm{P} \& \mathrm{O}$ concept, while the output of the fuzzy logic controller is the change in duty cycle $\Delta D$ of the boost converter. In this work, seven subsets for each input and for output and forty nine rules have been used. The proposed fuzzy rules of the system are shown in Table 3.

$$
\begin{aligned}
& \Delta P=P(k)-P(k-1) \\
& \Delta V=V(k)-V(k-1) \\
& E(k)=\frac{P(k)-P(k-1)}{V(k)-V(k-1)} \\
& C E(k)=E(k)-E(k-1)
\end{aligned}
$$

\section{SIMULATION}

The block diagram of proposed PV system which include PV array, boost converter, (P\&O and FLC) based MPPT controllers and DC load that simulated in Matlab/Simulink is shown in Fig. 18.

\section{RESULT AND DISCUSSION}

P\&O and FLC controllers based MPPT of PV system under $1000 \mathrm{~W} / \mathrm{m} 2$ and air temperature of $250 \mathrm{C}$ are implemented using Matlab/Simulink, the PV array output power is shown in Fig. 19. PV array maximum output power reached $65 \mathrm{KW}$ when subjected to $1000 \mathrm{~W} / \mathrm{m} 2$ at $250 \mathrm{C}$ verifying the capability of both techniques to produce maximum power of proposed PV system. From Fig. 19, it is noticed that both P\&O and FLC MPPT can track the maximum power point but FLC MPPT can track the maximum power faster than conventional P\&O MPPT. Also, the performances of MPPT using the FLC and the simple P\&O techniques at different environmental conditions such as irradiance level and air temperature are studied. The performance of P\&O and FLC based MPPT is investigated when the solar irradiation level is varied. Figure 20 indicates the PV array output power with P\&O and FLC controllers based MPPT at sudden irradiance decrease. The irradiance values are 1000, 750, 500 and $250 \mathrm{~W} / \mathrm{m} 2$ at fixed temperature of $25 \mathrm{oC}$. Figure 21 illustrates the PV array output power with P\&O and FLC based MPPT at sudden irradiance increase. The irradiance values are 250, 500, 750 and $1000 \mathrm{~W} / \mathrm{m} 2$ at air temperature of $25 \mathrm{oC}$. The results of simulation show that in case of FLC, the power generated by the PV solar array is more than that generated by $\mathrm{P} \& \mathrm{O}$ at certain level of radiation. This can be 
attributed to the driving of the PV array operation toward the optimum point in order to deliver the highest possible power; this is more evident in the high levels of solar radiation. Also, the performance of $P \& O$ and FLC based MPPT is investigated under variable values of air temperatures. Figure 22 illustrates the PV array output power with $\mathrm{P} \& \mathrm{O}$ and FLC at sudden decrease of temperature. The temperature values are 75,50 and 250 Cat radiation of $1000 \mathrm{~W} / \mathrm{m} 2$. The effect of sudden increase of temperature on performance of $\mathrm{P} \& \mathrm{O}$ and FLC is investigated for 25,50 and $75 \mathrm{oC}$ at radiation of $1000 \mathrm{~W} / \mathrm{m} 2$. From Fig. 23, it is observed that, PV output power is reduced as the air temperature increase and fuzzy logic based MPPT controller has provided more power than conventional P\&O MPPT at certain value of temperature. It is observed that intelligent controllers such as FLC have been performing well under sudden changes in the irradiation and temperature. State of charge (SOC) of the battery over the 24 hours for a typical summer and winter days are shown in Fig.24 and Fig. 25 respectively. There is a shortage or a surplus of energy supplied by the PV generator according to whether condition. Accordingly, PV may not easily satisfy loads during the period from 7 am to $5 \mathrm{pm}$ as the variation of solar electricity generation does not always match with the time distribution of load demand from 7 am to $5 \mathrm{pm}$. It is observed that, if PV generator not capable of satisfying the load the battery SOC decreased because it took over the responsibility of satisfying the load demand. As PV power is sufficient for supplying the load demand, and if there is a surplus, it is used for charging the battery and the battery SOC increases. In winter the SOC varied between $66.3 \%$ and $76.3 \%$ during the period of $7-5$ o'clock, while in summer the SOC varied between $98.6 \%$ and $99.9 \%$ during this period.

\section{CONCLUSION}

Optimization of stand-alone PV system for powering E-bike batteries charging station in Cairo, Egypt is presented. The optimum power system comprises of PV array of 65 $\mathrm{kW}$ and 80 SuretteS6CS25P batteries. The cost of energy (COE) is found to be 0.579 $\$ / \mathrm{kWh}$. Maximum power point tracking controllers are developed to maximize the PV array output power. The proposed P\&O controller and FLC are implemented to Boost DC-DC converter for tracking maximum power point. MATLAB-SIMULINK model for the PV system with P\&O controller and FLC is proposed. FLC shows better stable operating point than $\mathrm{P} \& \mathrm{O}$ controller. The performance of $\mathrm{P} \& \mathrm{O}$ controller and FLC is investigated when the solar irradiance level and the air temperature are varied. It is indicated that the changing of solar irradiance level has much greater effect on the PV output power than does the air temperature. Also, lower air temperature and higher solar irradiance level are required to get more power under the same PV system. Also, from the simulation results, it can be deduced that the FLC has better performance than $\mathrm{P} \& \mathrm{O}$ controller and it has more accuracy for operating at MPP. A significant contribution from battery bank is observed in winter to overcome the shortage of the PV generator power and satisfy the load demand. The proposed MPPT using FLC can improve the performance of the system and can drive quickly the system to the new MPP when an abrupt change of the MPP occurs. Finally, the experience of using Ebikes and installing solar battery charging stations can be applied successfully in tourism areas in Egypt, such as Luxor and Aswan. 


\section{REFERENCES}

[1] Nordic Folkecenter for Renewable Energy, "Charging Station for Electric Vehicles", June 2008, pp. 1-25.

[2] Thuy Thu TRINH , Hong thi Thanh PHAM , Ngoc thi Kim PHAM , "Study on Electric Bike Use in Vietnam", Proceedings of the Eastern Asia Society for Transportation Studies, Vol.10, 2015, pp. 1-14.

[3] https://en.wikipedia.org/wiki/Utility_cycling

[4] Gil Nadais, Célia Laranjeira, Aida Antunes, Daniela Herculano and Câmara Municipal de Águeda, " Pilot Project Beágueda - Electrical Bycicle Of Águeda: Case-Study", $\quad$ pp. 1-21, http://www.eltis.org/sites/eltis/files/casestudies/documents/paper_draft_glasgow_fin_0.pd.

[5] Robert Cong, Rodney Martinez, Mark Casilang and Peter Vong, " Electric Bike System", Senior Project, Electrical Engineering Department, California Polytechnic State University, San Luis Obispo and June 2010, pp. 1-57.

[6] Herman Jacobus Vermaak, Kanzumba Kusakana, " Design of a photovoltaic-wind charging station for small electric Tuk-tuk in D.R.Congo", Renewable Energy Vol. 67, 2014, pp. 40-45.

[7] Adel El-Menchawy, Hesham Bassioni, output Farouk, "Photovoltaic Systems in Existing Residential Building in Egypt", International Journal of Scientific \& Engineering Research Vol. 2, Issue 7, July-2011, pp. 1-11

[8] Egyptian solar radiation atlas, Cairo, Egypt, 1998.

[9] MY1016Z Electric Bike brushed DC Motor Specifications, Winner Group Onlybo Instruments Co., Ltd, http://olbo.en.alibaba.com/product/377253461 212014835/MY1016Z_Electric_Bike_Brushless_DC_Motor.html.

[10] National Renewable Energy Laboratory (NREL), "HOMER - Analysis of mircopower system options", https://analysis.nrel.gov/homer/default.asp.

[11] NREL, "HOMER, The Hybrid Optimization Model for Electric Renewable", Available from National Renewable Energy Laboratory HOMER: http://www.homerenergy.com.

[12] Homer, the Micropower Optimization Model, Homer Energy, LLC, Version 2.68 beta, www.homerenergy.com.

[13] Jetion Solar Vision Green Energy, "JT180PEe Multicrystalline 156x156 Module specifications" http://eng.sfe-solar.com/wp content/uploads/2014/ 10/SunFields Jetion-JT180-200PEe-Poly.pdf

[14] Hammad Abo-Zied Mohammed, Stand-alone Photovoltaic System for a Cabin in Marsa-allam", International Journal of Control, Automation and Systems", Vol.2, No.3, October 2013, pp.47-52.

[15] Surette6CS25P model battery specification, http://www.amerescosolar.com/ 6cs25p-6-volt-5000-series-1156-amphour-100 hr rate-deep-cycle-flooded-battery.

[16] Ahmad Al-Diab, Constantinos Sourkounis, "Variable Step Size P\&O MPPT Algorithm for PV Systems", 2010, 12th International Conference on Optimization of Electrical and Electronic Equipment, OPTIM 2010, pp. 1097-1102. Design and Optimization of Standalone Photovoltaic System 193

[17] S. Ganesh, J. Janani, G. Besliya Angel, " A Maximum Power Point Tracker for PV Panels Using SEPIC Converter", International Journal of Electrical, Computer, Energetic, Electronic and Communication Engineering Vol.8, No.2, 2014, pp. 356-361. 
[18] N. Tkouti, A. Moussi, "Maximum Power Point Tracker Using Genetic Fuzzy Controller for Photovoltaic Grid Connected Array" Courrier du Savoir - No. 19, 2015, pp.65-70.

[19] S. Lalouni, D. Rekioua, T. Rekioua, E. Matagne, "Fuzzy logic control of standalone photovoltaic system with battery storage", Journal of Power Sources, Vol. 193, 2009, pp. 899-907.

[20] H. Knopf, "Analysis, Simulation and Evaluation of Maximum Power Point Tracking (MPPT) Methods for a Solar Powered Vehicle," Master Thesis, Portland State University, 1999.

[21] Luis Castainer and Santiago Silvestre," Modeling Photovoltaic Systems using PSpice", john wiely \& Sons, 2002.

[22] Anju Jolly , F.T. Josh, " Optimization of Energy Management for Charged Storage of a PV System by the Fuzzy Logic Technique", International Journal of Computer Applications, Vol. 63, No.10, February 2013, pp. 19-24.

[23] Swati Singh, Lini Mathew, Shimi S.L.," Design and Simulation of Intelligent Control MPPT Technique for PV Module Using MATLAB/ SIMSCAPE", International Journal of Advanced Research in Electrical, Electronics and Instrumentation Engineering, Vol. 2, Issue 9, September 2013, pp. 4554-4566.

[24] S. Karthika ,Dr. P. Rathika, Dr. D. Devaraj, " Fuzzy Logic Based Maximum Power Point Tracking Designed for 10kW Solar Photovoltaic System", International Journal of Computer Science and Management Research Vol. 2, Issue 2, February 2013, pp. 1421-1427.

[25] A. Al Nabulsi, R. Dhaouadi, " Fuzzy Logic Controller Based Perturb and Observe Maximum Power Point Tracking', International Conference on Renewable Energies and Power Quality (ICREPQ'12), Santiago de Compostela (Spain), 28th to 30th March, 2012, pp. 1-6.

[26] H.E.A. Ibrahim and Mahmoud Ibrahim," Comparison Between Fuzzy and P\&O Control for MPPT for Photovoltaic System Using Boost Converter", Journal of Energy Technologies and Policy, Vol.2, No.6, 2012, pp. 1-12.

[27] Po-Chen Cheng, Bo-Rei Peng, Yi-Hua Liu, Yu-Shan Cheng and Jia-Wei Huang, "Optimization of a Fuzzy-Logic-Control-Based MPPT Algorithm Using the Particle Swarm Optimization Technique", Energies, Vol. 8, 2015, pp. 5338-5360.

[28] Areen Abdallah Allataifeh, Khaled Bataineh, Mohammad Al-Khedher," Maximum Power Point Tracking Using Fuzzy Logic Controller under Partial Conditions", Smart Grid and Renewable Energy, Vol. 6, 2015, pp. 1-13.

[29] H. Assem, F. Bouchafa, A. Hadj Arab and B. Bouzidi," Fuzzy logic controller in optimizing of power management in stand-alone photovoltaic system", Revue des Energies Renouvelables SIENR'14 Ghardaïa, 2014, pp. 41 - 48.

[30] Dib Djalel, Mordjaoui Mourad, and Abdulhabeb Abdulhabeb" A Contribution to Study of a GPV System MPPT with (P\&O) and (FLC) algorithms". 


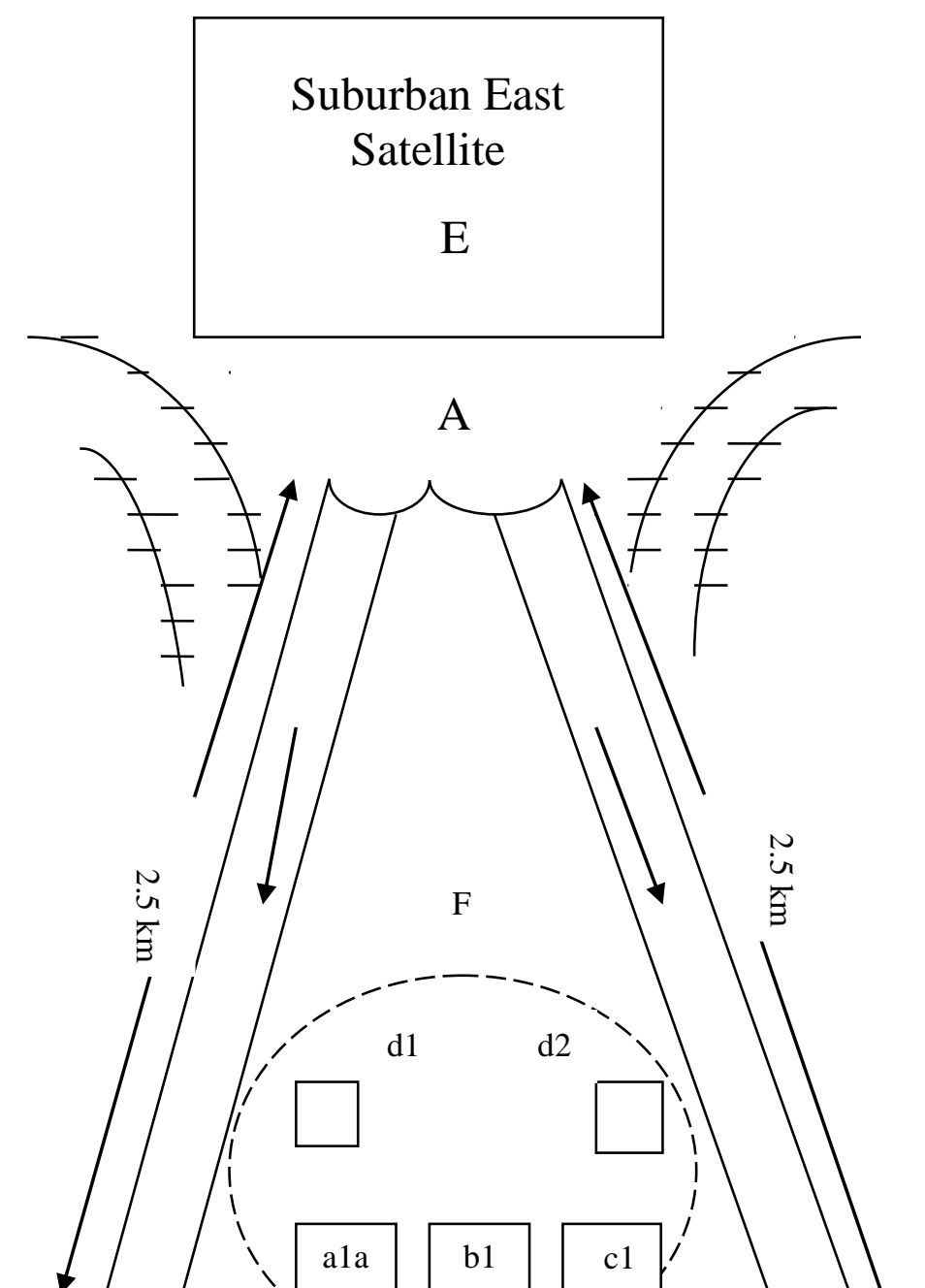


Proceedings of the 11 $^{\text {th }}$ ICEENG Conference, 3-5 April, 2018

Fig.1 Diagram of how to apply this experience.

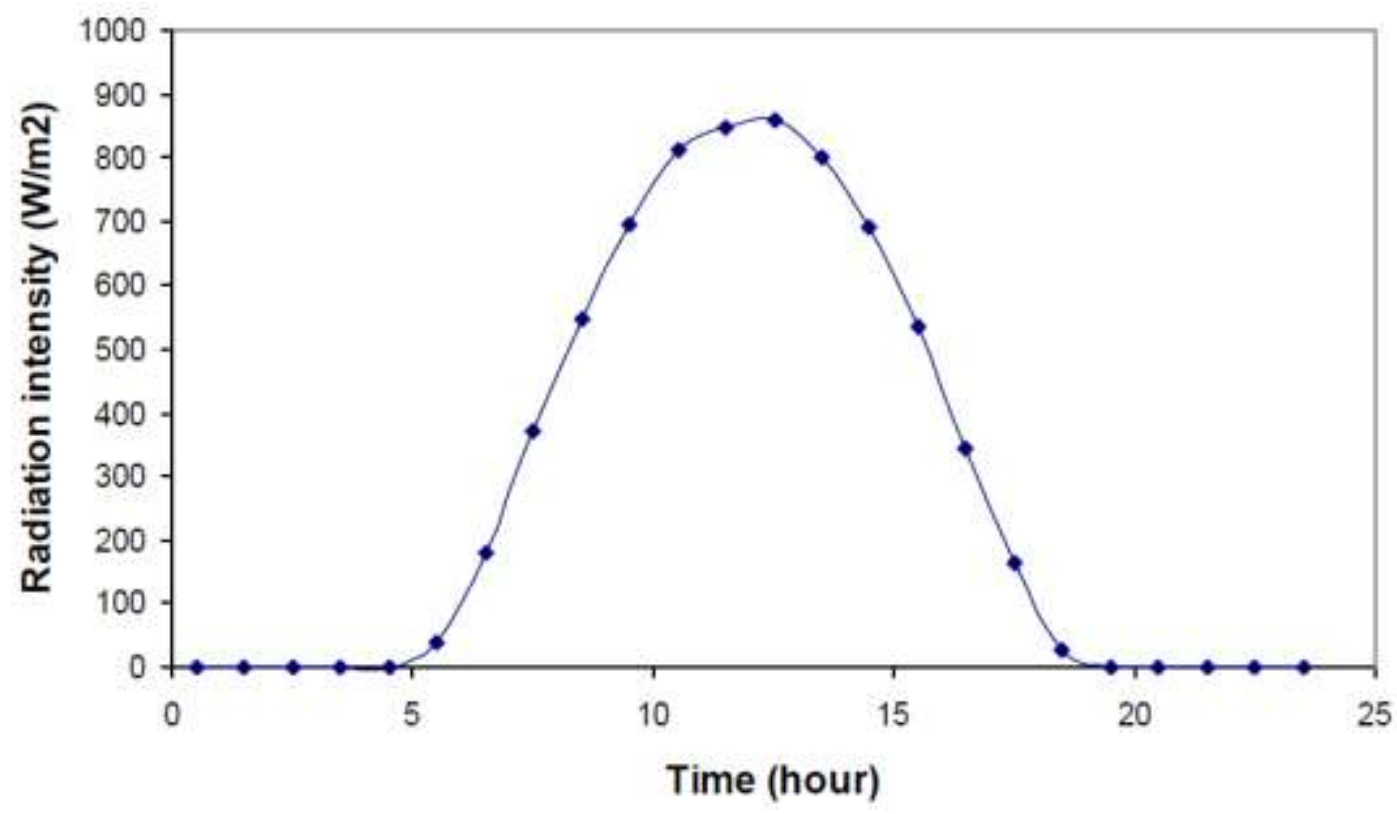

Fig. 2 Solar radiation of Cairo for a typical day in summer. 
Proceedings of the 11 $^{\text {th }}$ ICEENG Conference, 3-5 April, 2018

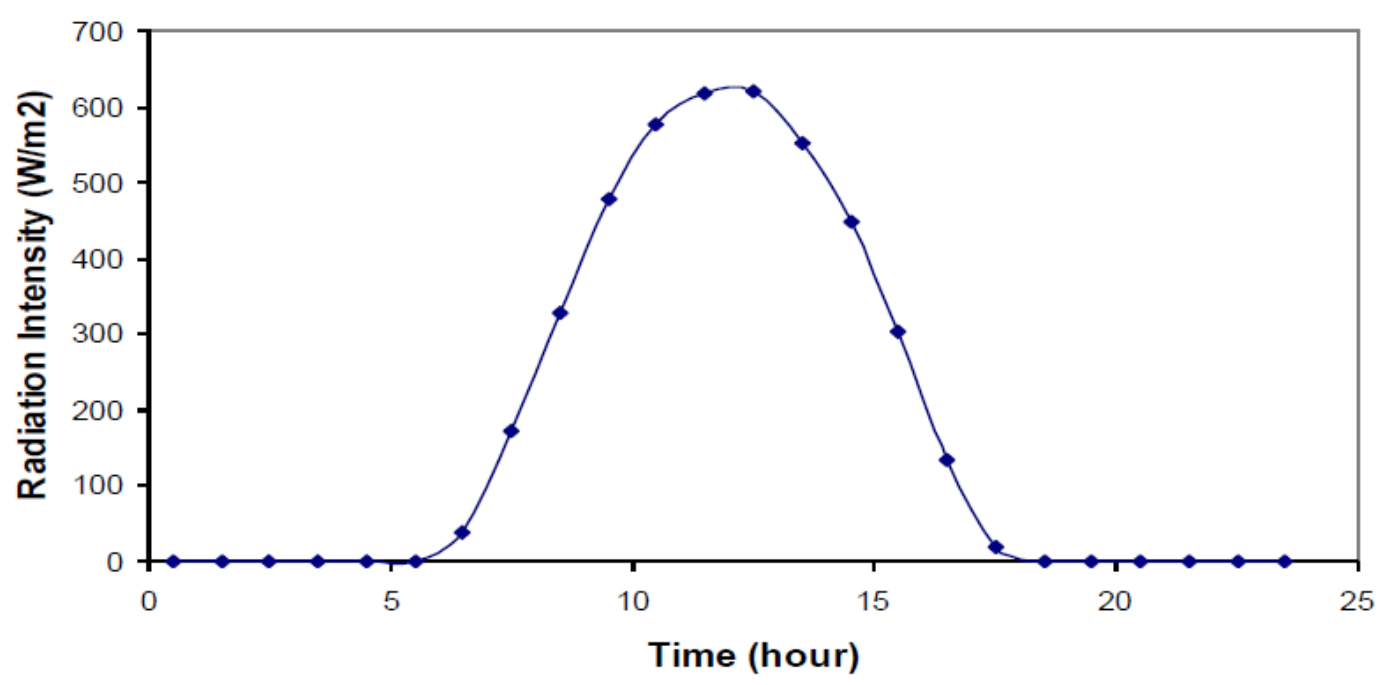

Fig. 3 Solar radiation of Cairo for a typical day in winter.

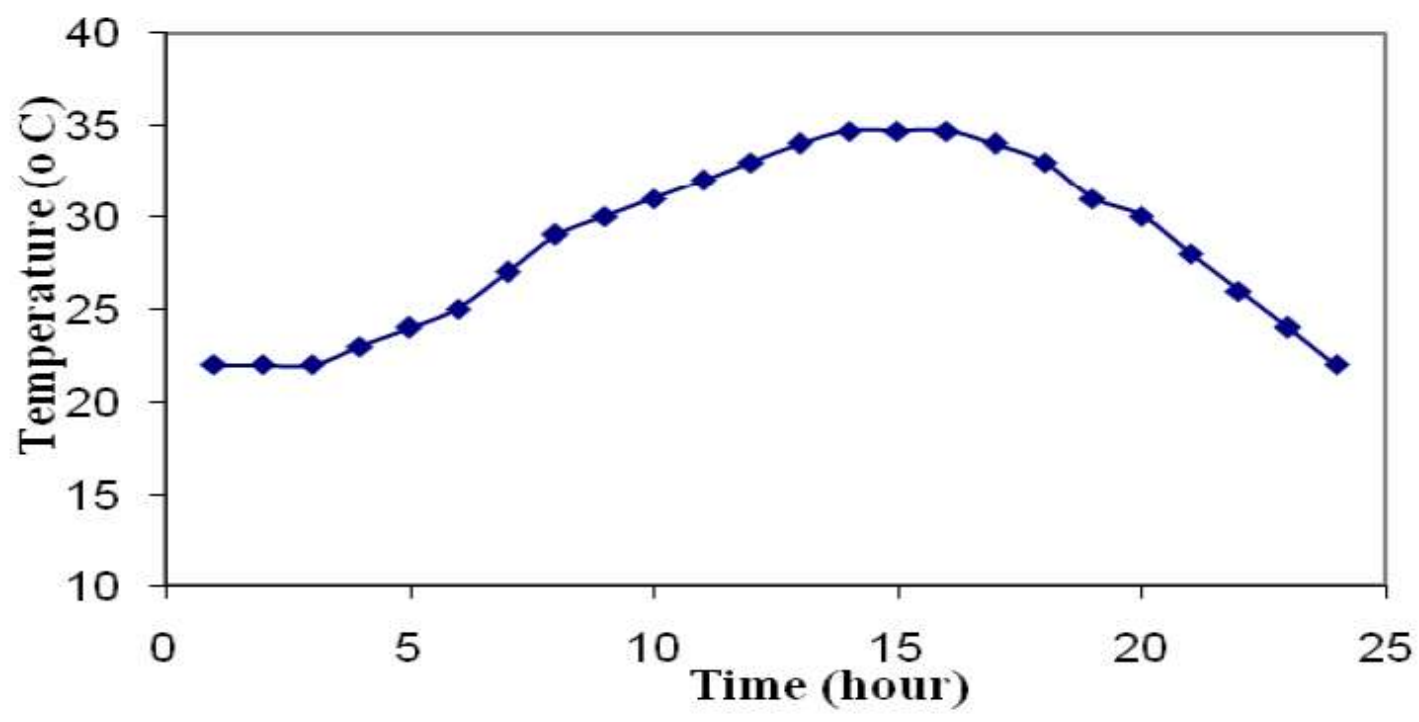

Fig. 4 Ambient temperature of Cairo for a typical day in summer . 


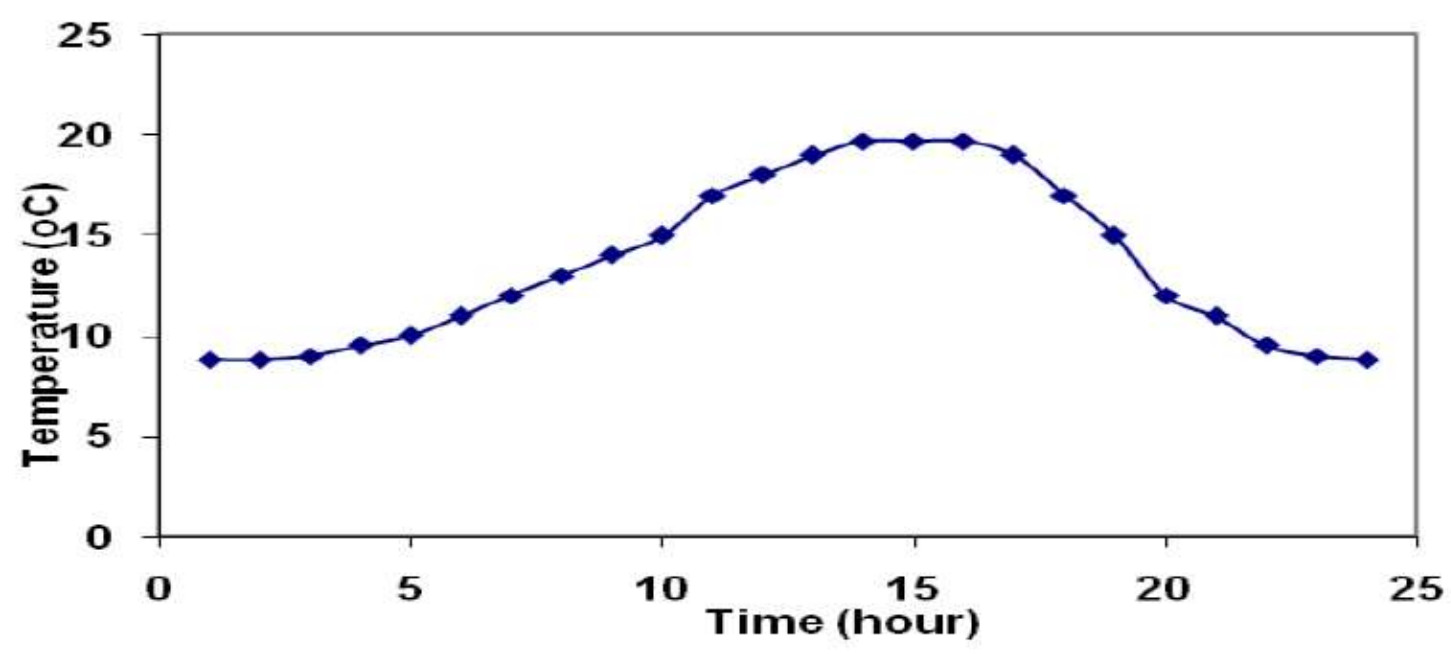

Fig. 5 Ambient temperature of Cairo for a typical day in winter.

Table 1: Specification of MY1016Z Motor

\begin{tabular}{|c|c|}
\hline Model & MY1016Z \\
\hline Power/Voltage & $250 \mathrm{~W} / 24 \mathrm{~V}$ \\
\hline No-load RMP/rpm & 3850 \\
\hline No-load current/A & $\leq 2.5$ \\
\hline Rated RMP/rpm & 3000 \\
\hline Toque/N.m & 0.80 \\
\hline Rated current/A & $\leq 13.4$ \\
\hline Efficiency/\% & $\geq 78 \%$ \\
\hline
\end{tabular}




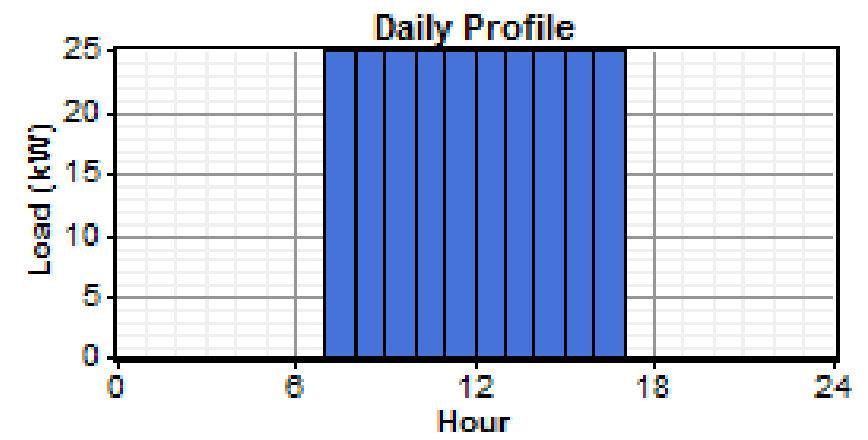

Fig.6 Daily load profile of the battery charging station

Table 2: PV module specification: JT180PEe: Multi-Crystalline Silicon156×156 module

\begin{tabular}{|c|c|}
\hline Parameter & Value \\
\hline Max-Power & $180 \mathrm{~W}$ \\
\hline Max-Power Voltage $\mathrm{V}_{\mathrm{m}}(\mathrm{V})$ & $24.4 \mathrm{~V}$ \\
\hline Max-Power Current $\mathrm{I}_{\mathrm{m}}(\mathrm{A})$ & $7.4 \mathrm{~A}$ \\
\hline Open-Circuit Voltage $\mathrm{V}_{\mathrm{oc}}(\mathrm{V})$ & $29.2 \mathrm{~V}$ \\
\hline Short-Circuit Current $\mathrm{I}_{\mathrm{sc}}(\mathrm{A})$ & $8.16 \mathrm{~A}$ \\
\hline Module Efficiency $(\%)$ & 13.7 \\
\hline $\mathrm{P}_{\mathrm{m}}$ Temperature Coefficients $\left(\% /{ }^{\circ} \mathrm{C}\right)$ & -0.43 \\
\hline $\mathrm{V}_{\mathrm{oc}}$ Temperature Coefficients $\left(\% /{ }^{\circ} \mathrm{C}\right)$ & -0.32 \\
\hline $1_{\mathrm{sc}}$ Temperature Coefficients $\left(\% /{ }^{\circ} \mathrm{C}\right)$ & 0.049 \\
\hline
\end{tabular}

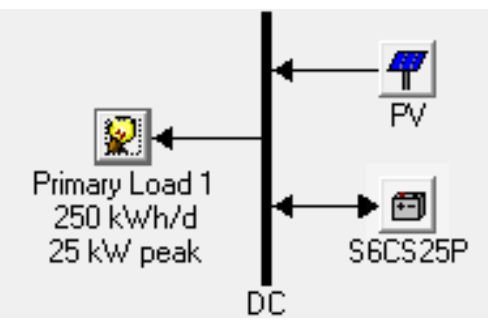

Fig.7 Proposed PV system configuration by HOMER

\begin{tabular}{|c|c|c|c|c|c|c|c|}
\hline$\$ \oplus \mid$\begin{tabular}{c|c}
$P V$ \\
$(\mathrm{~kW})$
\end{tabular} & S6CS25P & $\begin{array}{c}\text { Initial } \\
\text { Capital }\end{array}$ & $\begin{array}{l}\text { Operating } \\
\text { Cost (\$/yr) }\end{array}$ & $\begin{array}{l}\text { Total } \\
\text { NPC }\end{array}$ & \begin{tabular}{|c|}
$\mathrm{COE}$ \\
$(\mathrm{s} / \mathrm{kWh})$
\end{tabular} & $\begin{array}{l}\text { Ren. } \\
\text { Frac. }\end{array}$ & \begin{tabular}{|l} 
Capacity \\
Shortage
\end{tabular} \\
\hline$\Theta$ & 80 & $\$ 351,600$ & 21,758 & $\$ 629,743$ & 0.579 & 1.00 & 0.09 \\
\hline
\end{tabular}

Fig. 8 The optimization results of PV system 


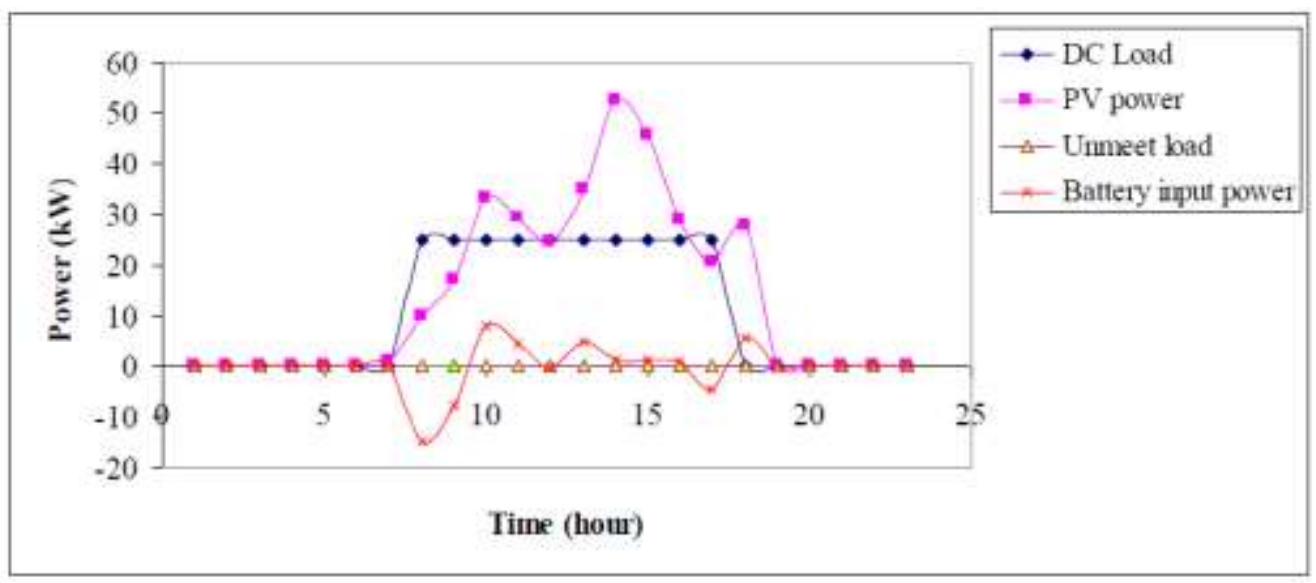

Fig. 9 The daily distribution of the generated PV output power, battery input power, DC primary load and unmet load for a typical day in summer

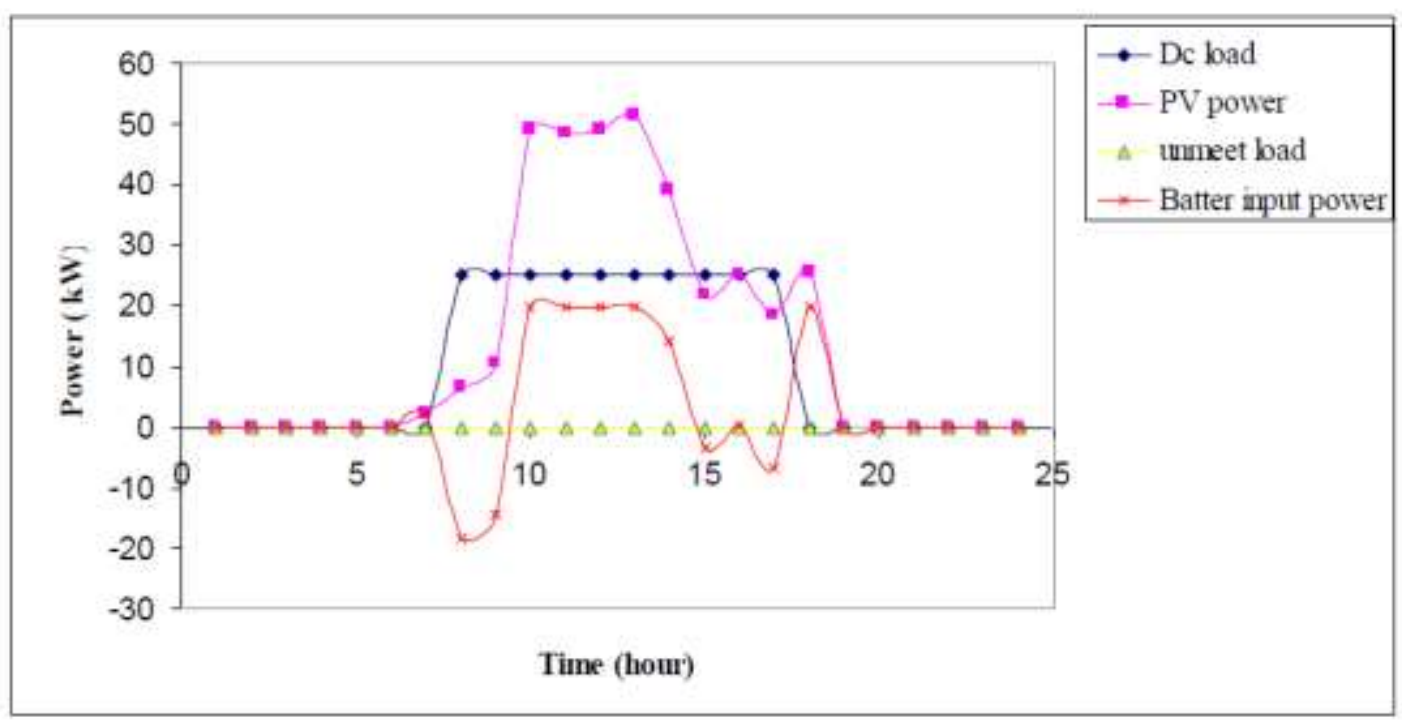

Fig. 10 The daily distribution of the generated PV output power, battery input power, DC primary load and unmet load for a typical winter day 


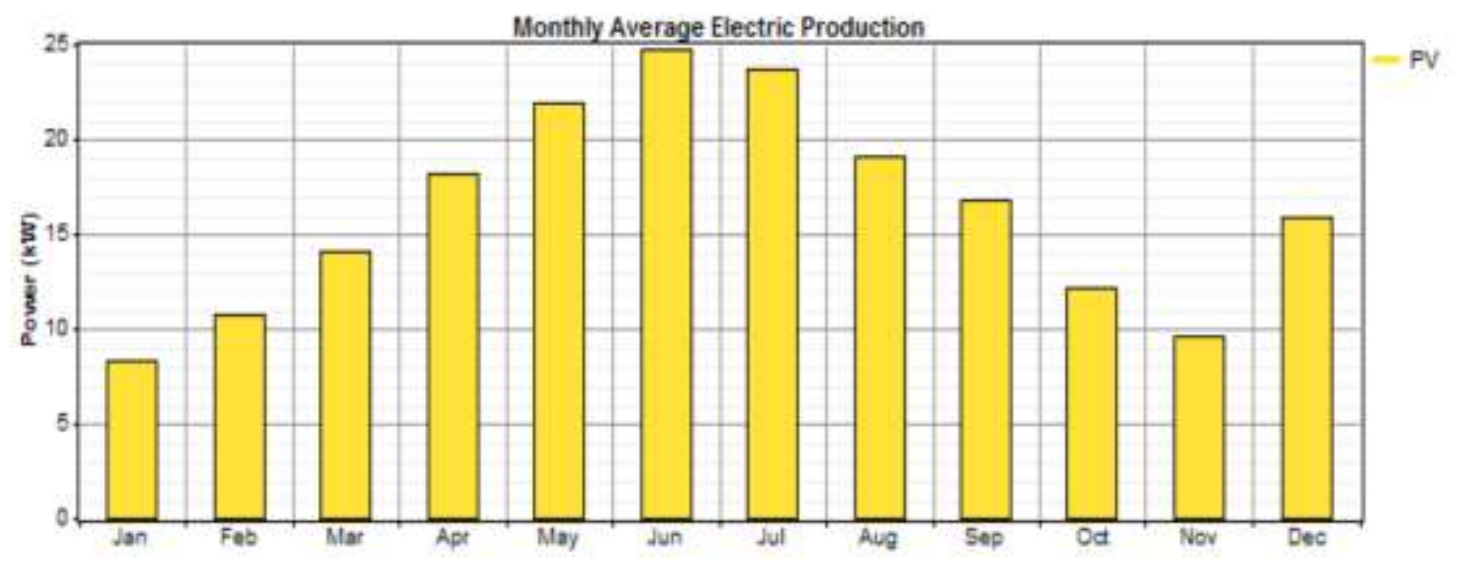

Fig. 11 Monthly electricity production by PV array

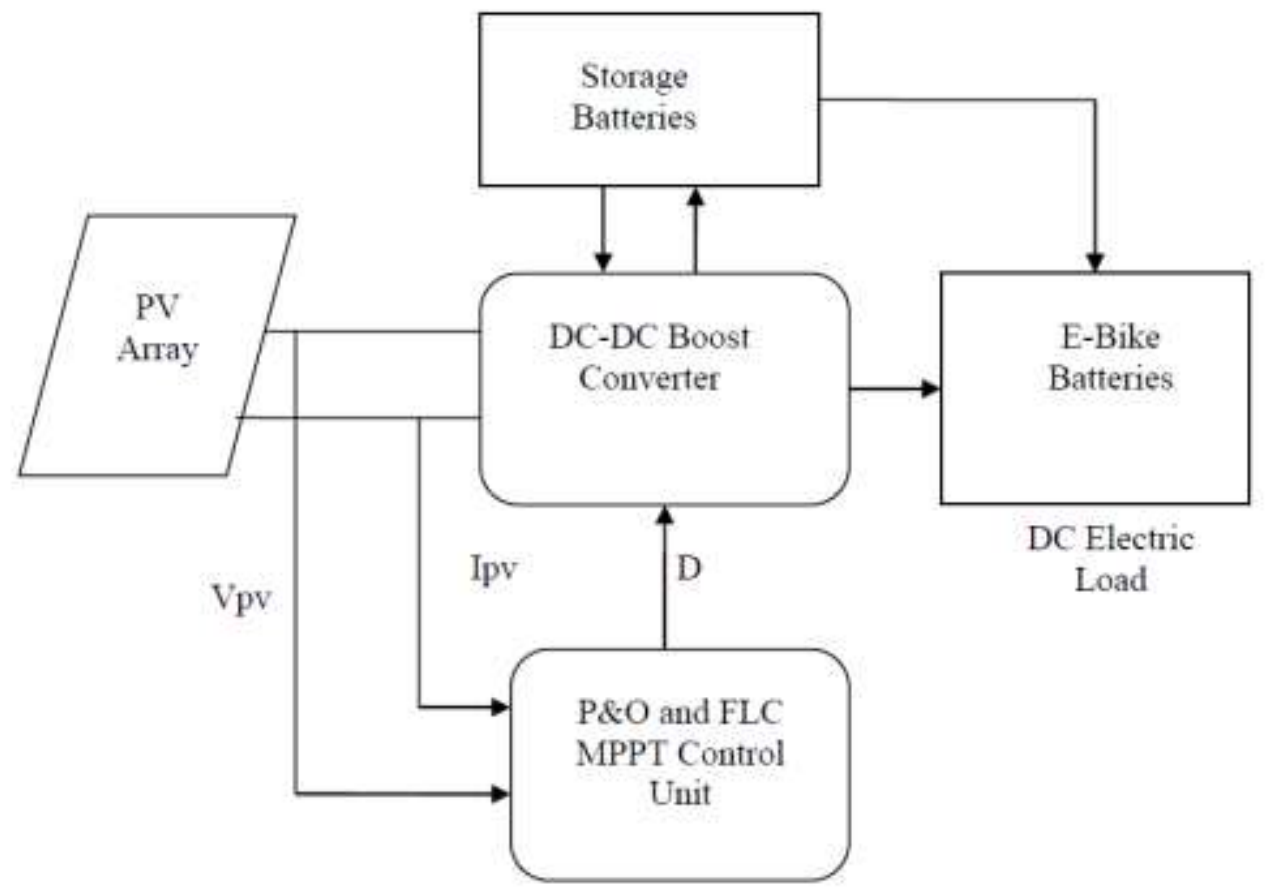

Fig. 12 Block diagram of the P\&O controller and FLC for the PV system

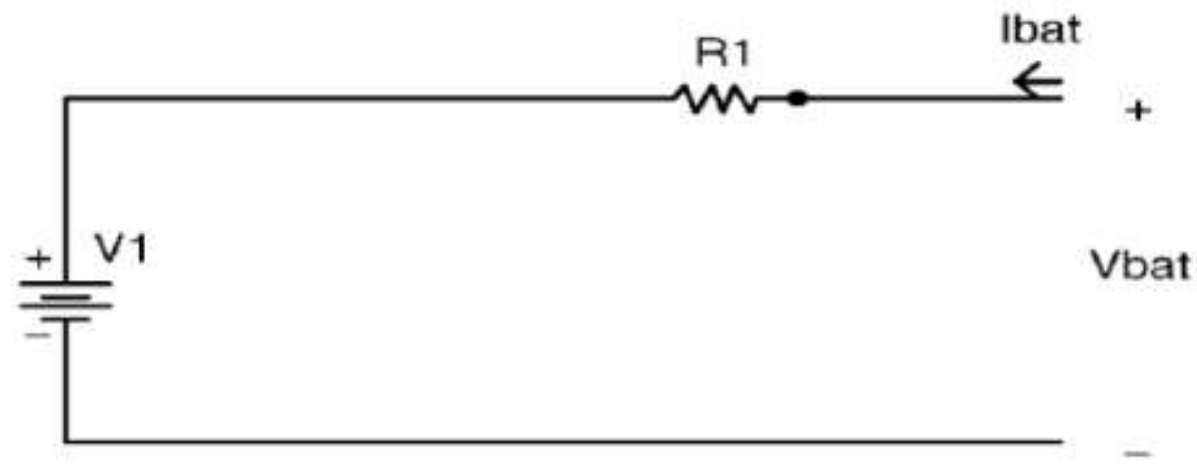

Fig. 13 Battery model 


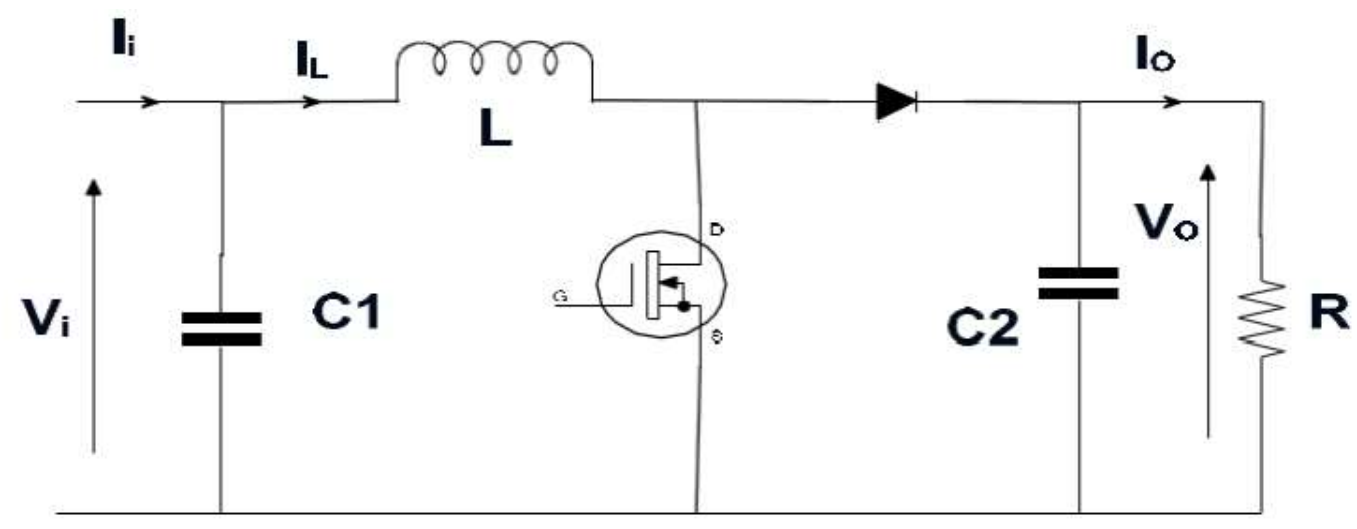

Fig.14 DC-DC buck-boost converter circuit diagram

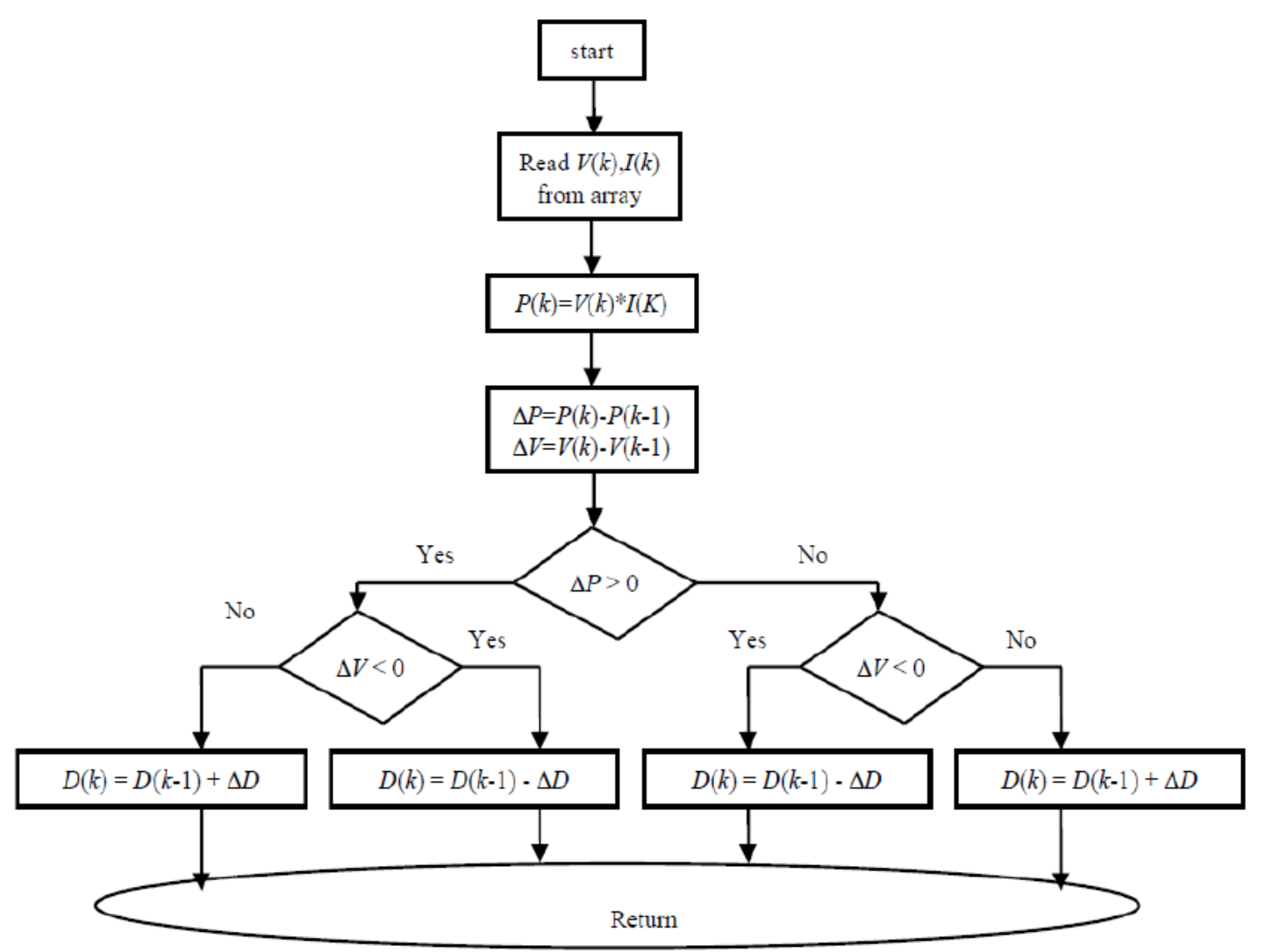

Fig.15 Flow chart of P\&O 


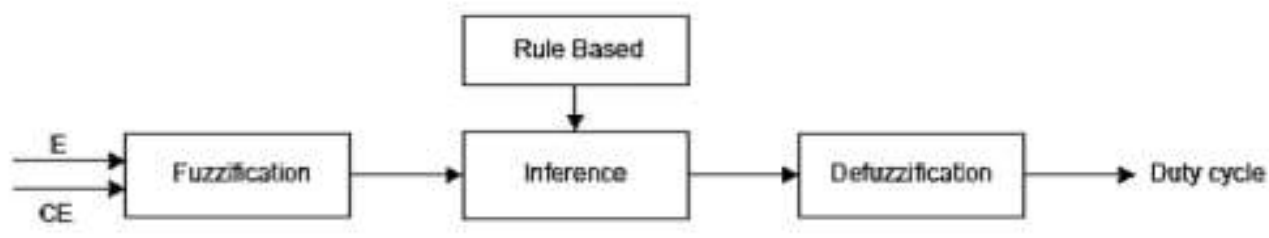

Fig. 16 Structure of a fuzzy logic controller.

Table 3 Rules of the fuzzy controller.

\begin{tabular}{|c|c|c|c|c|c|c|c|}
\hline $\begin{array}{c}\text { CE(K) } \\
\text { E(K) }\end{array}$ & NB & NM & NS & ZE & PS & PM & PB \\
\hline NB & NB & NB & NB & NB & NM & NS & ZE \\
\hline NM & NB & NB & NM & NM & NS & ZE & PS \\
\hline NS & NB & NM & NS & NS & ZE & PS & PM \\
\hline ZE & NB & NM & NS & ZE & PS & PM & PB \\
\hline PS & NM & NS & ZE & PS & PS & PM & PB \\
\hline PM & NS & ZE & PS & PM & PM & PB & PB \\
\hline PB & ZE & PS & PM & PB & PB & PB & PB \\
\hline
\end{tabular}

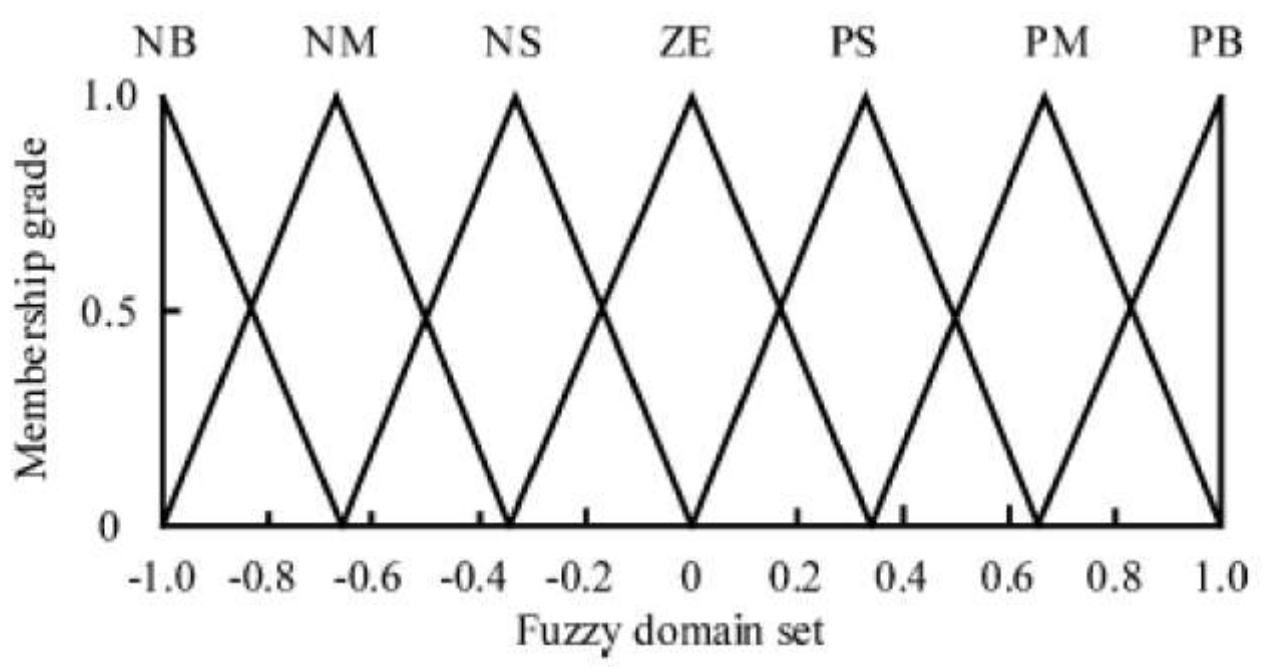

Fig. 17 Membership functions of the two inputs; error (E), change of error (CE) and the output 


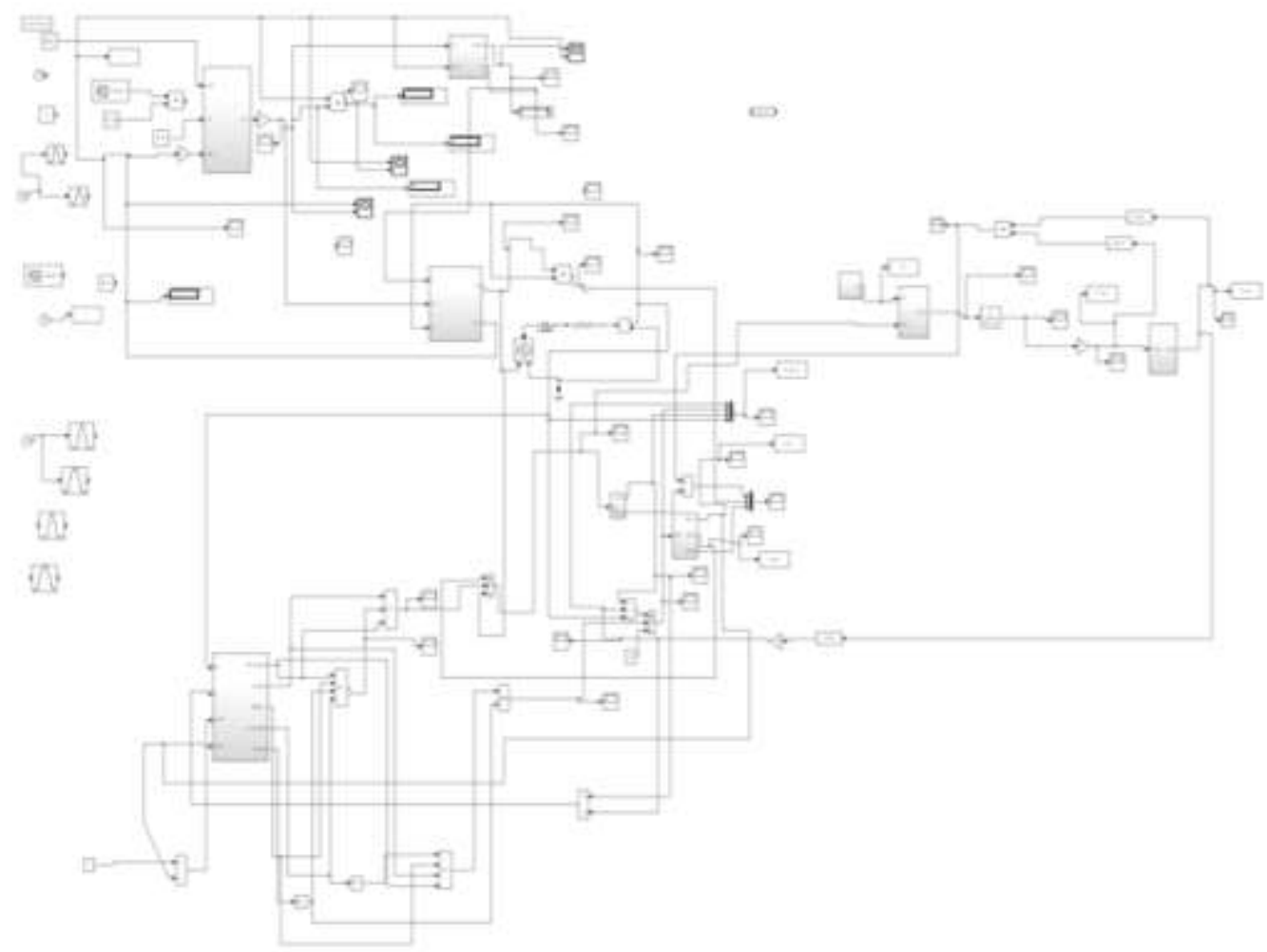

Fig. 18 Simulink block diagram of PV standalone system with P\&O controller and FLC

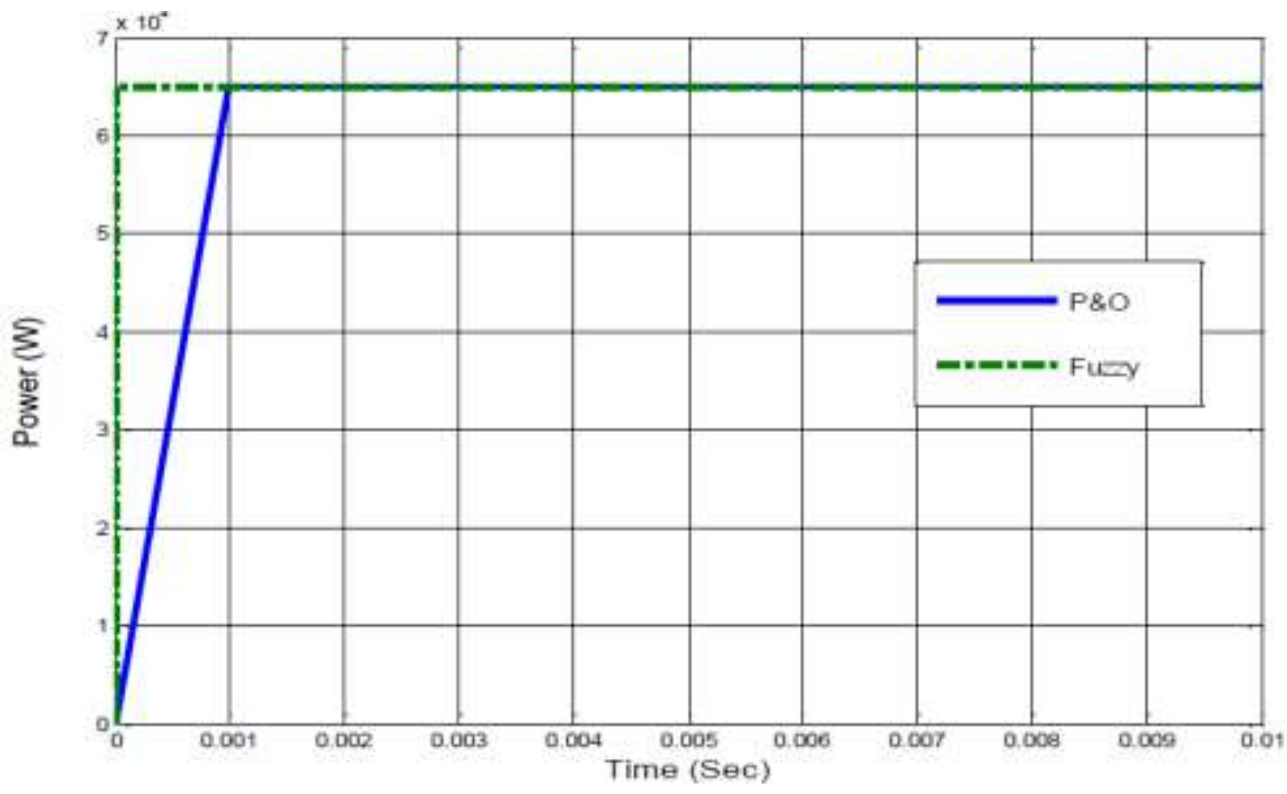

Fig. $19 \mathrm{PV}$ array output power with $\mathrm{P} \& \mathrm{O}$ controller and FLC at irradiance level of $1000 \mathrm{~W} / \mathrm{m} 2$ and $250 \mathrm{C}$ 


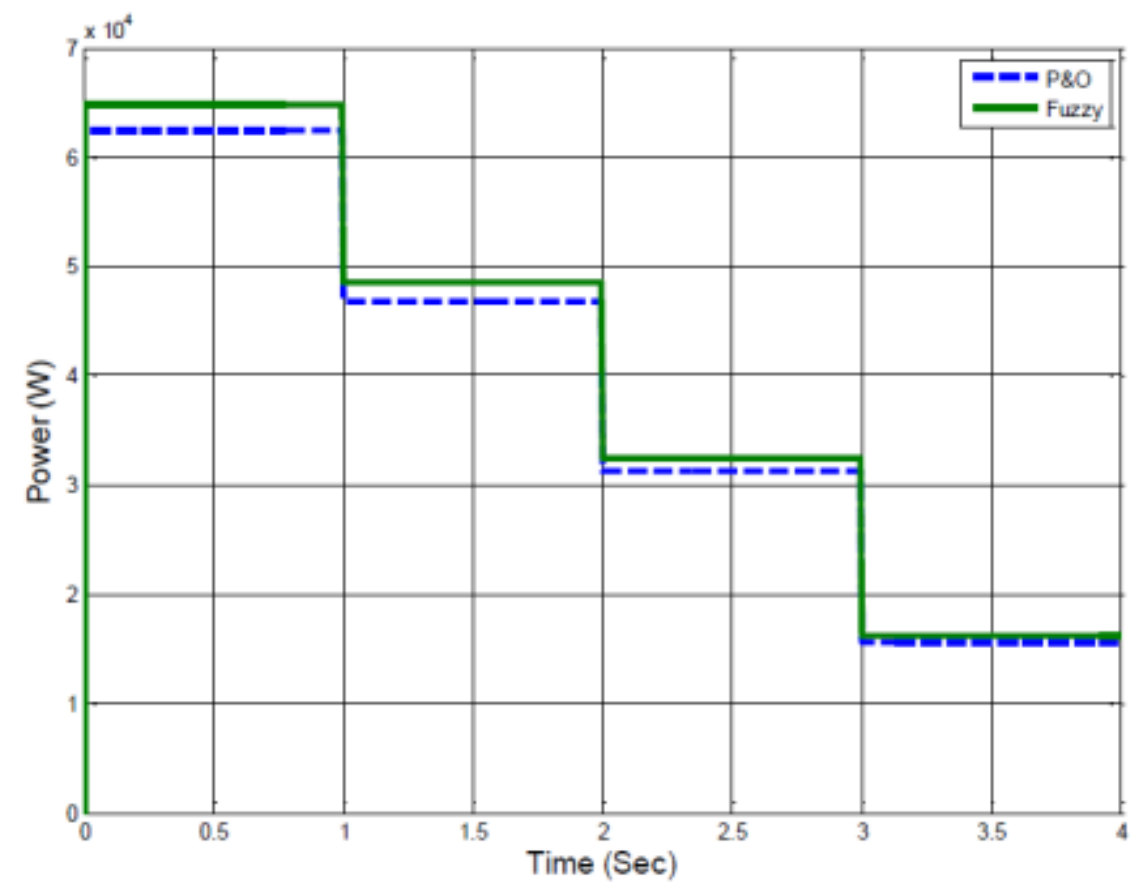

Fig. $20 \mathrm{PV}$ array output power with $\mathrm{P} \& \mathrm{O}$ controller and FLC at $250 \mathrm{C}$ and sudden decrease of irradiance level $(1000,750,500$ and $250 \mathrm{~W} / \mathrm{m} 2)$

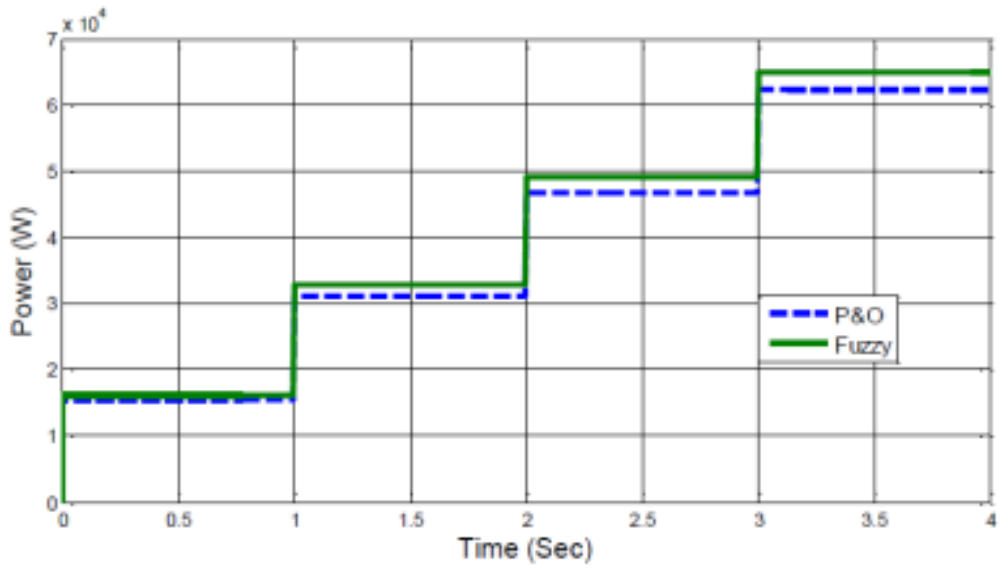

Fig.21 PV array output power with P\&O controller and FLC at 25oC and sudden increase of irradiation $(250,500,750$ and $1000 \mathrm{~W} / \mathrm{m} 2)$ 


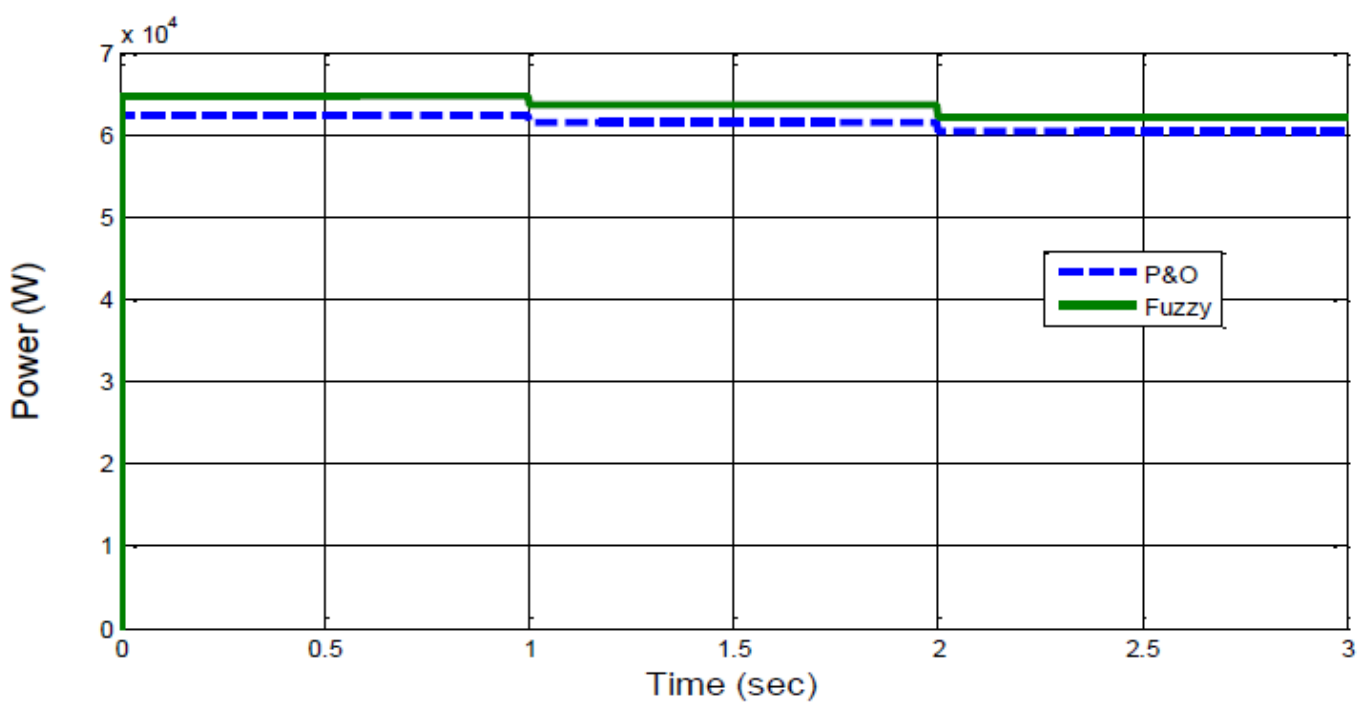

Fig.22 PV array output power with P\&O controller and FLC at $1000 \mathrm{~W} / \mathrm{m} 2$ and sudden increase of temperature $(25,50$ and $750 \mathrm{C})$

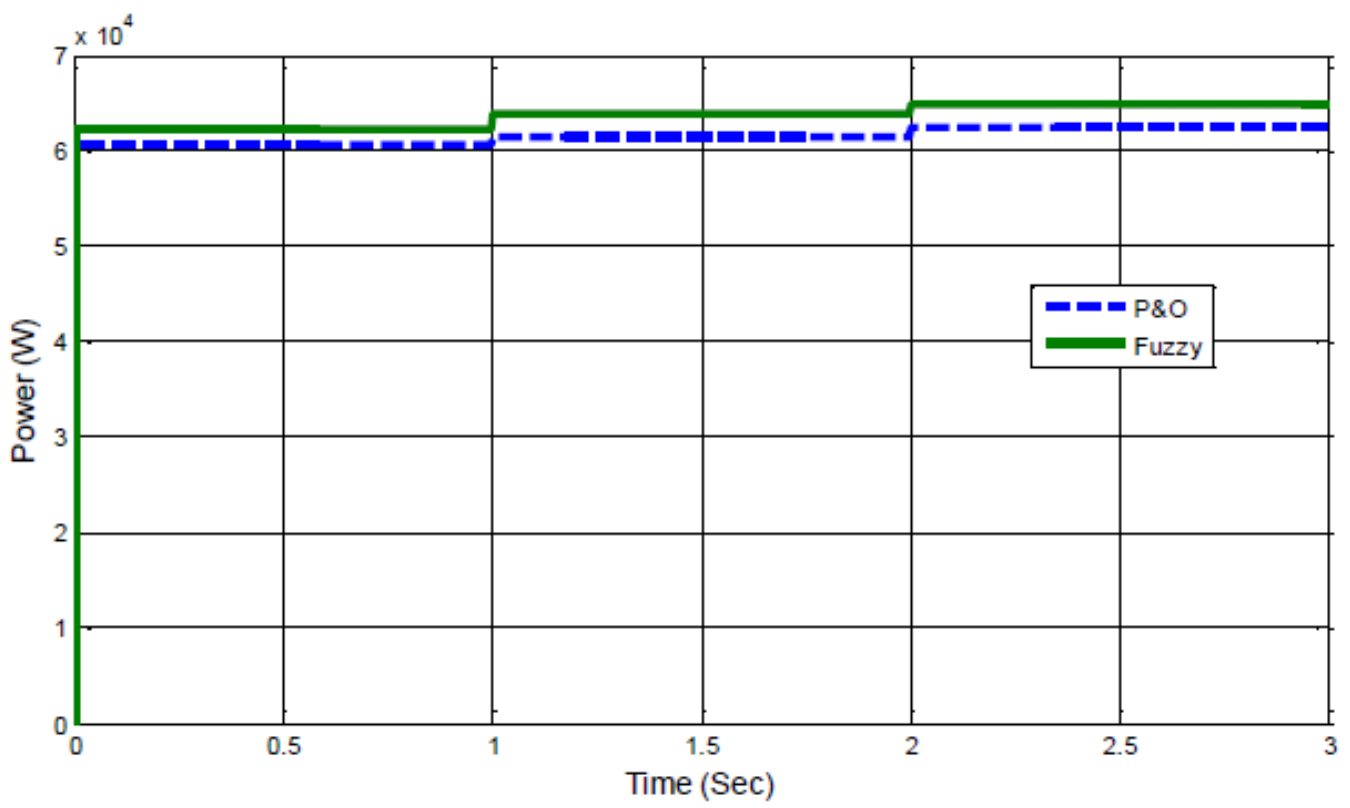

Fig. $23 \mathrm{PV}$ array output power with P\&O controller and FLC at $1000 \mathrm{~W} / \mathrm{m} 2$ and sudden decrease of temperature $(75,50$ and $250 \mathrm{C})$ 
Proceedings of the $\mathbf{1 1}^{\text {th }}$ ICEENG Conference, 3-5 April, 2018

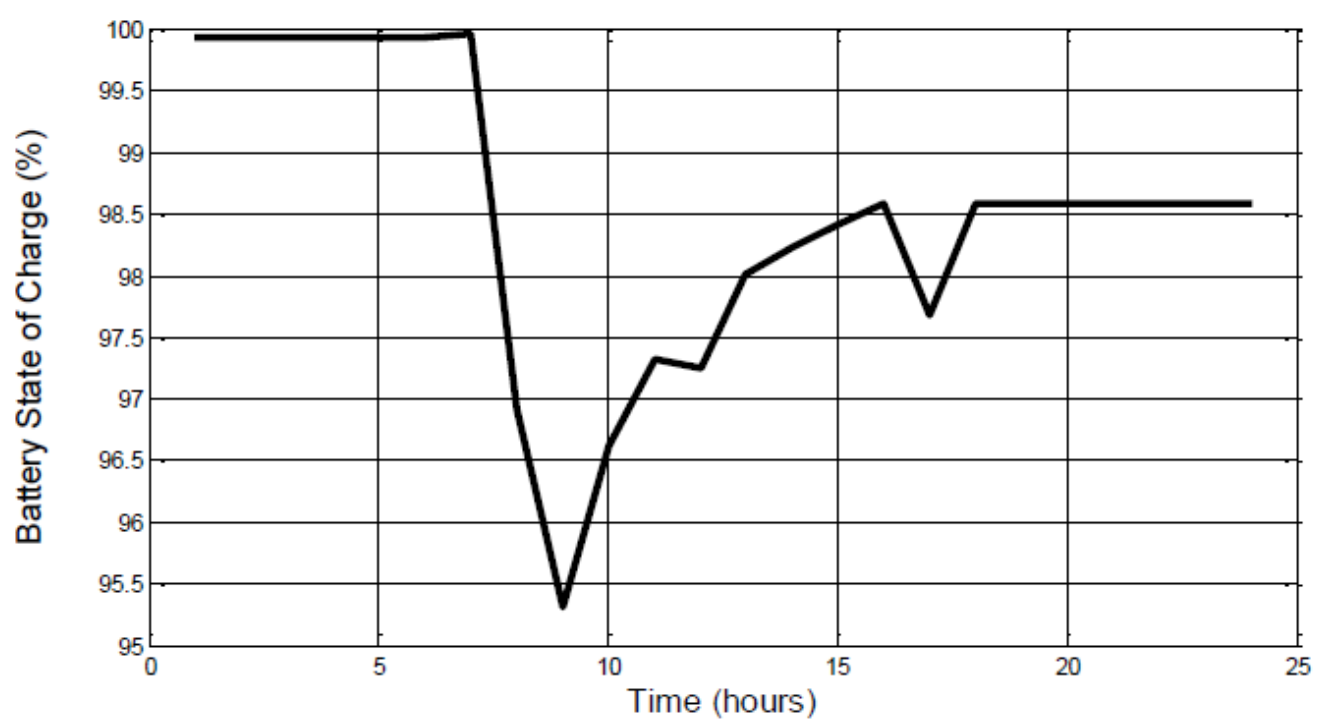

Fig. 24 Battery state of charge for a typical summer day

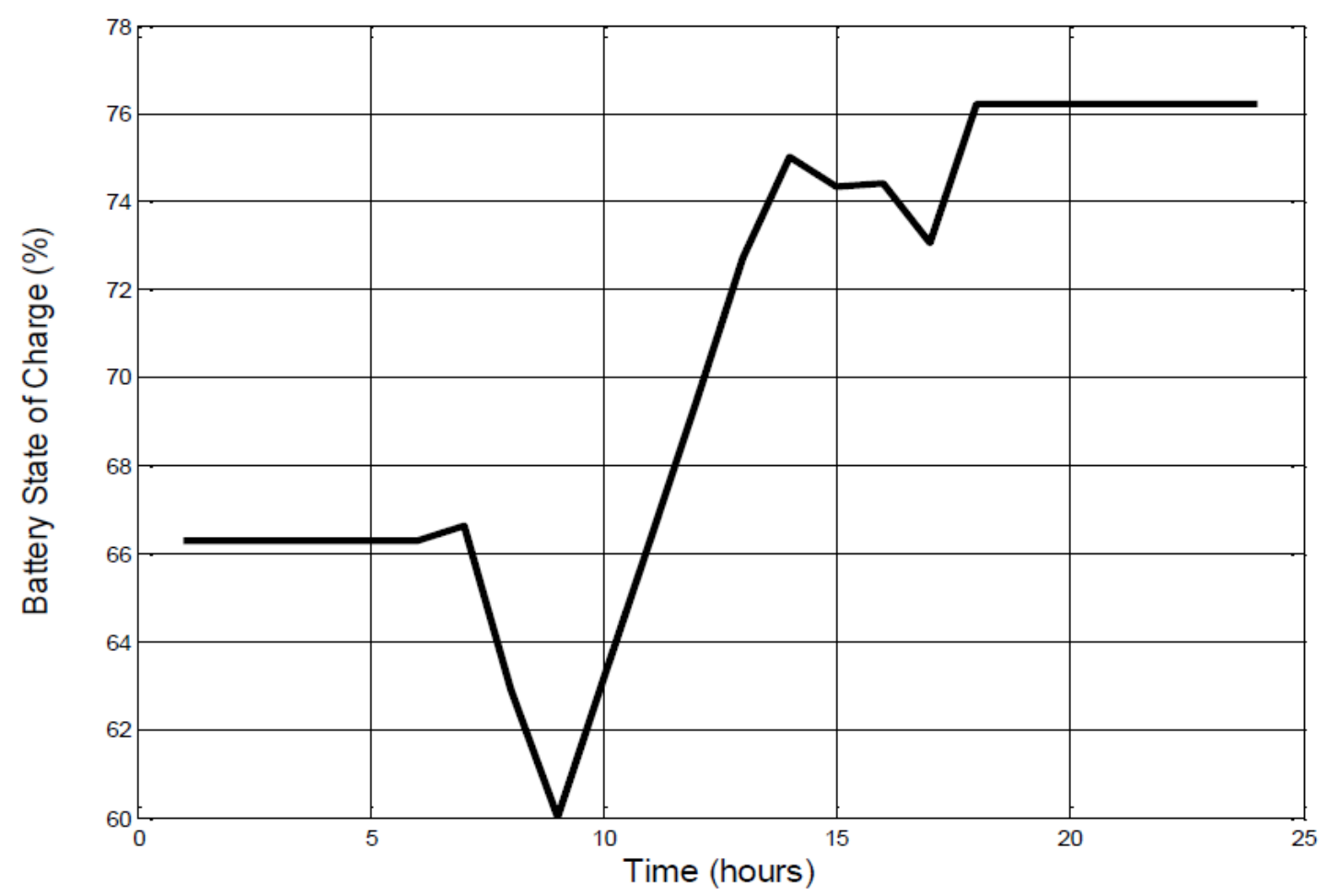

Fig. 25 Battery state of charge for a typical winter day 